\title{
5
}

\section{Early Detection and Prevention of Breast Cancer: The Increasing Importance of Midwives in the Future}

\author{
Andrej Plesničar ${ }^{1}$, Klaudia Urbančič ${ }^{1}$, Suzana Mlinar ${ }^{1}$, Božo Kralj², \\ Viljem Kovač ${ }^{3}$ and Blanka Kores Plesničar ${ }^{4}$ \\ ${ }^{1}$ University of Ljubljana, Faculty of Health Sciences, Ljubljana \\ ${ }^{2}$ University of Ljubljana, Faculty of Medicine, Ljubljana \\ ${ }^{3}$ Institute of Oncology, Ljubljana \\ ${ }^{4}$ University of Maribor, Faculty of Medicine, Maribor \\ Slovenia
}

\section{Introduction}

Breast cancer (BC) is the most common type of cancer and cause of death from cancer in women in the Republic of Slovenia. As in the majority of other economically and industrially developed countries, the incidence rate of BC is increasing in Slovenia and has reached 111.8 cases per 100,000 women in 2008. The incidence rate of $\mathrm{BC}$ has thus shown more than a fivefold increase in the period from 1950 to 2008 and BC was diagnosed in 1,147 women in 2008 (Cancer Registry of Republic of Slovenia, 2010). Similar increases in the incidence rates of BC have in the last decades also been observed in a number of other economically and industrially developed countries with aging female population (Curado et al (Eds.), 2009). However, the incidence rates of the BC are also rapidly increasing in a number of low- and middle-income countries (LMIC) (Forouzanfar et al, 2011), with more than half of all deaths caused by BC globally occurring in these countries (Curado et al (Eds.), 2009; Forouzanfar et al, 2011; International Agency for Research in Cancer, 2008). In LMIC countries, a sizeable proportion of women killed by BC were aged 15-49 years (Forouzanfar et al, 2011).

In the period from the year 1954 to the year 2006 a number of demographic changes took place in Slovenia (population two million) that may have contributed to the increase in the incidence rate of $\mathrm{BC}$ in recent decades. Major changes were observed in the size and age of population, in the number of live births annually, in the number of live births per 1,000 population, in total fertility rate, the age of mother at first birth and the age of mother at birth in total. In detail, the population of Slovenia grew from 1,521,485 to 2,008,516 in the period from 1954 to 2006, but simultaneously a decrease was observed in the number of live births annually, in the number of live births per 1,000 population and in total fertility rate (Ilić et al., 2008). On the other hand, an increase was observed in the age of mother at first birth and the age of mother at birth in total in the same period (Ilić et al., 2008). The data about population by sex are available only for the period from mid-1969 on and of all the people living in Slovenia on June 30th of that 
year, 826,145 were men and 887,877 were women. In mid-2006, 986,876 were men and $1,022,644$ were women, and the population of both sexes had been growing older in the decades prior to 2006. A substantial increase in the mean age of women at death was observed in the period from 1961 to 2006, reflecting an overall increase in age in Slovenian population in recent decades (Ilić et al., 2008).

In this report, the authors assess the possible impact of changes in some of the demographic indicators in Slovenia on the increase in the incidence rate of $\mathrm{BC}$ and therefore also on the possible role of midwives in the early detection and prevention of $\mathrm{BC}$ in the future. With regard to the recent increases of the incidence rates of $\mathrm{BC}$ in a number of LMIC countries, it may be plausible to consider the evolution and broadening of the role of midwives in the early detection and prevention of BC in these countries as well.

\section{Changes in some of the demographic indicators and simultaneous increase in the incidence rate of breast cancer in recent decades in Slovenia}

The data concerning the changes in some of the demographic indicators and simultaneous increase in the incidence rate of BC in Slovenia were collected and downloaded from open access electronic databases of the National Institute of Public Health of the Republic of Slovenia (National Institute of Public Health of the Republic of Slovenia, 2011), Statistical Office of the Republic of Slovenia (Statistical Office of the Republic of Slovenia, 2011), Slora-Slovenia and Cancer (Slora, 2011) of the Cancer Registry of Republic of Slovenia and from some of the similar sources (Cancer Registry of Republic of Slovenia, 2010; Curado et al (Eds.), 2009; Ilić et al., 2008). In this report the data in the figures refer only to the period from 1961 to 2006 since the data from periods earlier than 1961 are subject to limited availability. The data were processed and presented with the use of Excel 97 for Windows software package.

As already mentioned above, $\mathrm{BC}$ is the most common type of cancer and most common cause of death from cancer in Slovenia (Cancer Registry of Republic of Slovenia, 2010; Slora 2011). The incidence rate of BC has been increasing constantly in the last five decades (Figure 1). In a large part of this period, from 1961 to 2006, a simultaneous decrease had been observed in the number of live births annually, in the number of live births per 1,000 population and in total fertility rate (Ilić et al, 2008; Slora, 2011; Statistical Office of the Republic of Slovenia, 2011). The number of live births decreased from 31,828 to 18,932 in the period from 1961 to 2006 (Figure 2), the number of live births per 1,000 population decreased from 18.1 to 9.4 (Figure 3), and total fertility rate decreased from 2.26 to 1.31 in the same period (Figure 4). Conversely, for at least a part of this period, from late-seventies and early-eighties onward, the age of mother at first birth and the age of mother at birth in total both increased (Figure 5) (Ilić et al., 2008; Slora, 2011; Statistical Office of the Republic of Slovenia, 2011). The age of mother at first birth increased from 24.7 years in 1961 to 28 years in 2006, the lowest age of mother at first birth in this period was 22.7 years, observed in 1976, and the age of mother at birth in total increased from 27.7 years in 1961 to 29.7 years in 2006, the lowest age of mother at birth in total in this period was 25.3 years, observed in 1979, 1980 and in 1984 (Figure 5). (Ilić et al., 2008; Statistical Office of the Republic of Slovenia, 2011). Finally, the mean age at death of women increased from 59.8 years in 1954 to 78.1 years in 2006 (Figure 6) (Ilić et al., 2008; Slora, 2011; Statistical Office of the Republic of Slovenia, 2011). 


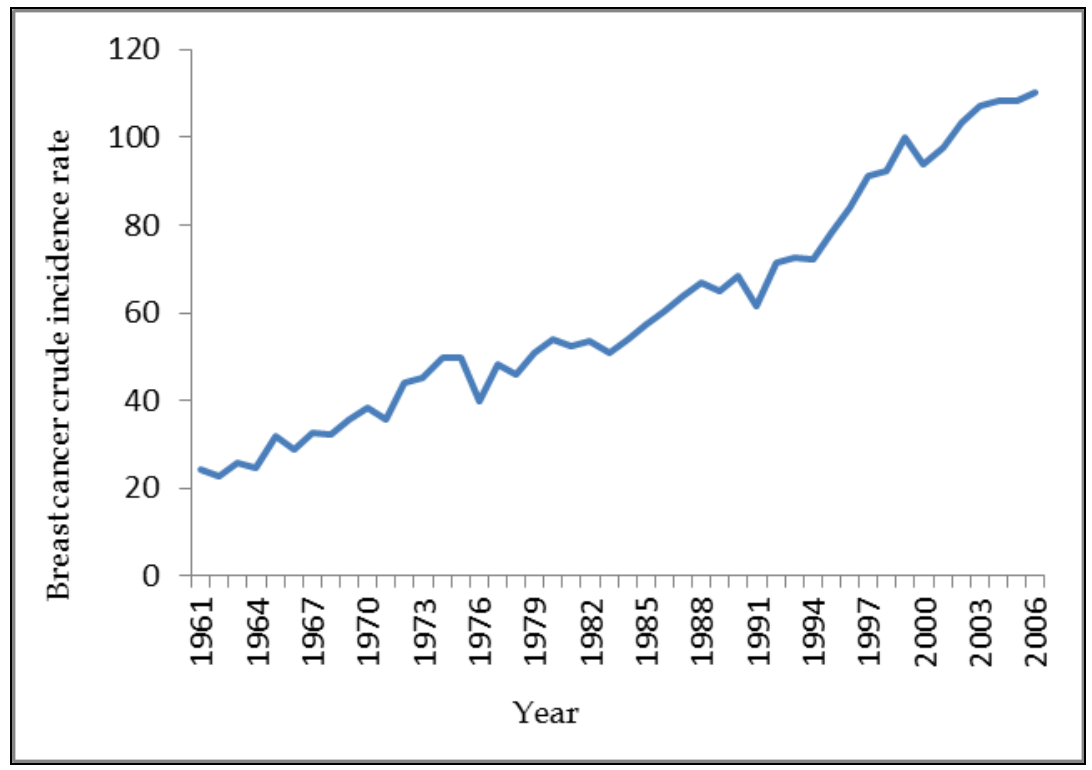

Fig. 1. Breast cancer crude incidence rate (blue line; definition: crude incidence rate is the number of new cases of disease or the number of deceased from the disease, calculated per 100,000 of population-persons, living in observed population in the middle of the time interval, usually one year (Slora, 2011; Statistical Office of the Republic of Slovenia, 2011)) in the period from 1961 to 2006 in Slovenia

Considering the changes in some of the aforementioned demographic factors and the corresponding increase in the incidence rate of BC in Slovenia, it is easy to imagine that these changes represent an increase in the risk of BC in women in the period from 1961 to 2006 in this country. Some additional data about changes in population in Slovenia in the recent decades in the following text may corroborate this notion.

As already suggested, the population of both sexes had aged quite rapidly in Slovenia. In 2006 the mean age of the population overall was 40.7 years; 39 years of men and 42.3 years of women. In the period between 1986 and 2006, the population of Slovenia has on average grown older by 5.6 years, by the end of this period men were on average older by 5.7 years and women by 5.6 years. The mean age of men grew the most between 1997 and 1998, and of women between 2001 and 2002 (Ilić et al., 2008). In 2006 the proportion of young population aged $0-14$ years was $14 \%$ and the proportion of population aged 65 years or more was $15.7 \%$. In the twenty years from 1986 to 2006 the number of individuals in population aged 0-14 years decreased by more than a third $(34.8 \%)$ and the number of individuals in population aged 65 years or more increased by more than a half (59\%) (Ilić et al, 2008). In just ten years, in the period from 1996 to 2006, the number of women in reproductive age (15-49 years) in Slovenia decreased from 518,335 in 1996 to 476,853 in 2006 (Ilić et al, 2008). In 1954 slightly over a third of children were first-born and almost $20 \%$ of mothers had at least four children, while in the last three decades of the period from 1954 to 2006 approximately half of all births were first order births (49.6\% in 2006), more than one 
third of births were second order births (35.8\% in 2006), slightly more than $10 \%$ were third order births $(10.9 \%$ in 2006$)$ and only about $3 \%$ of births were fourth order births or higher (3.7\% in 2006) (Ilić et al., 2008).

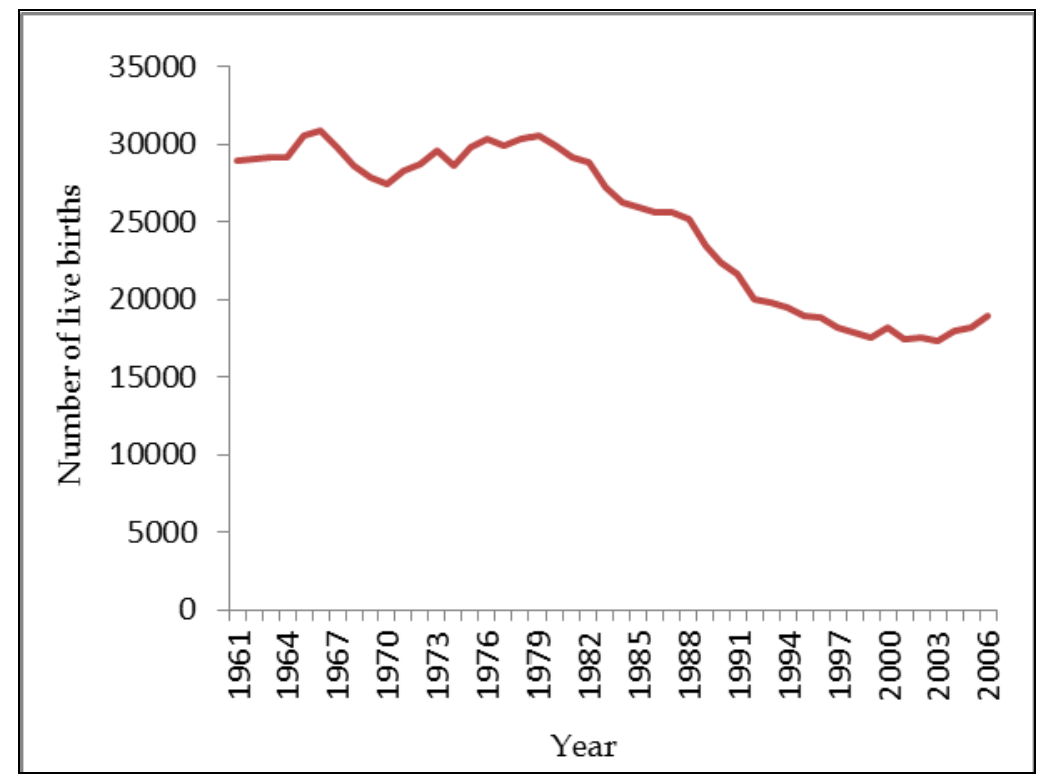

Fig. 2. Number of live births (red line; definition: number of live born children in the calendar year) in the period from 1961 to 2006 in Slovenia

In addition, it was also possible to retrieve some further data, for the period from 1954 to 1961, for the age of mother at first birth and the age of mother at birth in total, both risk factors for BC. Altogether, the age of mother at first birth rose from 24.8 years in the year 1954 to 28.0 years in the year 2006. The age of mother at birth in total rose from 28.4 years in 1954 to 29.7 years in 2006 (Ilić et al, 2008). Postponement of birth of the first child is typical for women of many European Union countries, especially in the lowest-low fertility countries. In some of these countries the trends in postponing of births is so intense that annual increase in the mean age is 0.2 years, with extremely fast postponement occurring in Slovenia, Hungary and the Czech Republic. In the United Kingdom, the mean age of women that gave birth to their children for the first time reached 30 years in 2006 (Ilić et al, 2008).

On the whole, increased risk of BC is associated with female gender, advancing age and age during menstrual life, hormonal factors (early menarche and late menopause), nulliparity and age of over 30 years at first birth, obesity and estrogen therapy after the menopause, harmful drinking of alcohol and history of benign proliferative lesions in the breast (Armstrong \& Nguyen, 1999; Bryant, 2004; Cancer Registry of Republic of Slovenia, 2010; Curado et al (Eds.), 2009; Henderson et al, 1996; International Agency for Research in Cancer, 2008; Soerjomataram et al, 2008). Risk of BC is also increased in women with one or more first-degree relatives with BC (Henderson et al, 1996), and with inherited mutations of any one of major genes, like BRCA1, BRCA2 and several others (Armstrong \& Nguyen, 1999; International Agency for Research in Cancer, 2008). 


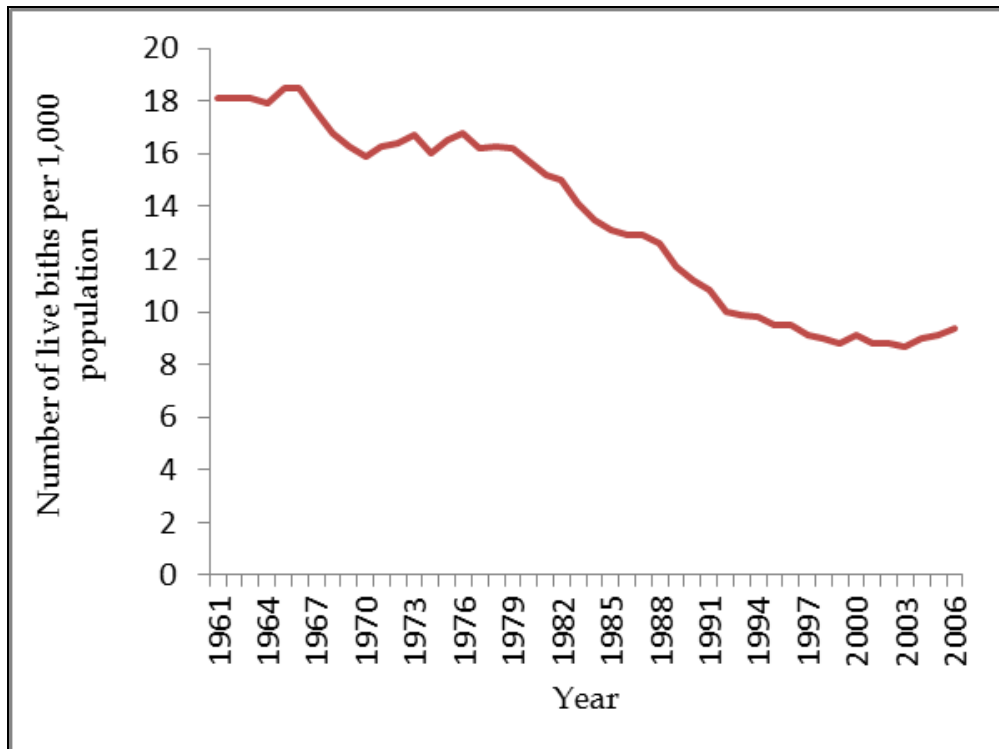

Fig. 3. Number of live births per 1,000 population (red line; definition: ratio between the number of live born children in the calendar year and the same mid-year population, multiplied by 1,000 (Ilić et al., 2008)) in the period from 1961 to 2006 in Slovenia

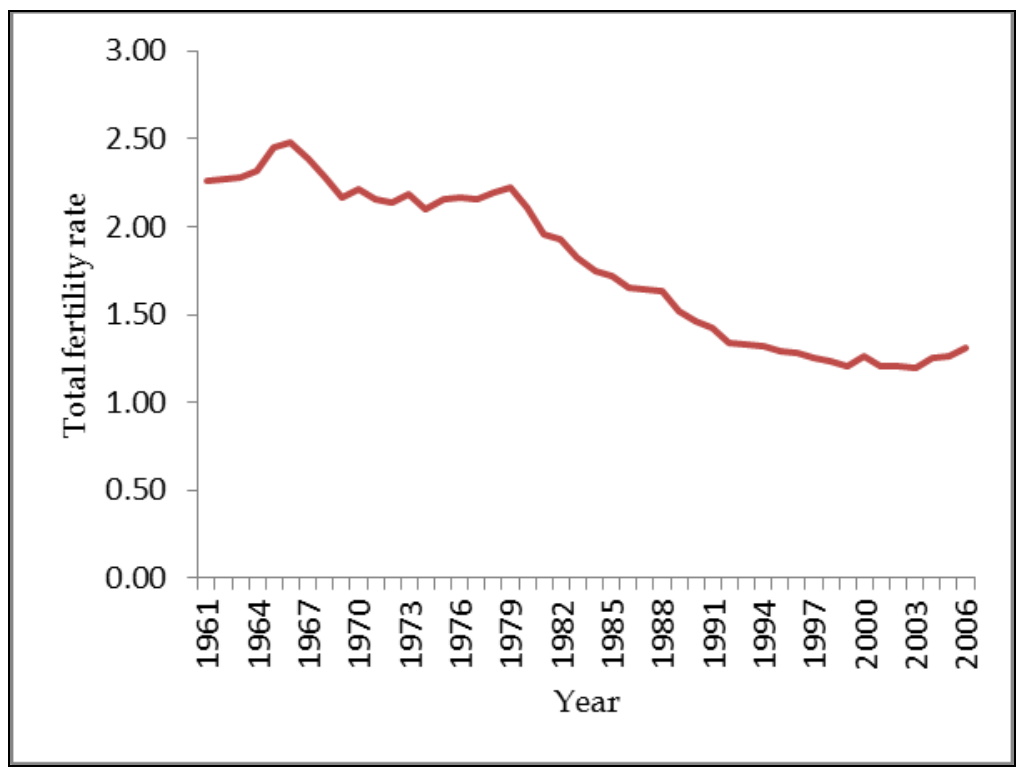

Fig. 4. Total fertility rate (red line; definition: the average number of live born children per one woman in reproductive age (15-49 years) in the calendar year (Ilić et al., 2008)) in the period from 1961 to 2006 in Slovenia 
It may be of particular interest that the number of women diagnosed with $\mathrm{BC}$ in the year 2008 in Slovenia is slightly lower than in the year 2007, when the incidence rate of BC reached 112.9 cases per 100,000 and when BC was diagnosed in 1,156 women (Cancer Registry of Republic of Slovenia, 2010; Slora, 2011). However, the incidence rates of BC are still notably lower in Slovenia than in the United States of America and in a number of other developed European Union countries. It remains to be seen if this small decrease in the incidence rate of $\mathrm{BC}$ in Slovenia represents the same type of trend as observed in the United States of America, where the incidence rates of BC decreased by approximately two percent annually in the period from 1999 to 2005 (Centers for Disease Control and Prevention, 2007; Kerlikowske et al, 2007). Later analysis showed that the incidence rate for BC stabilized in the period from 2003 to 2007, following a sharp decrease between 2002 and 2003 observed in women aged 50 years or more (DeSantis et al, 2011a, 2011b), that was associated with the decrease in the use of postmenopausal hormonal replacement therapy (DeSantis et al, 2011b; Kohler et al. 2011; Ravdin et al, 2007).

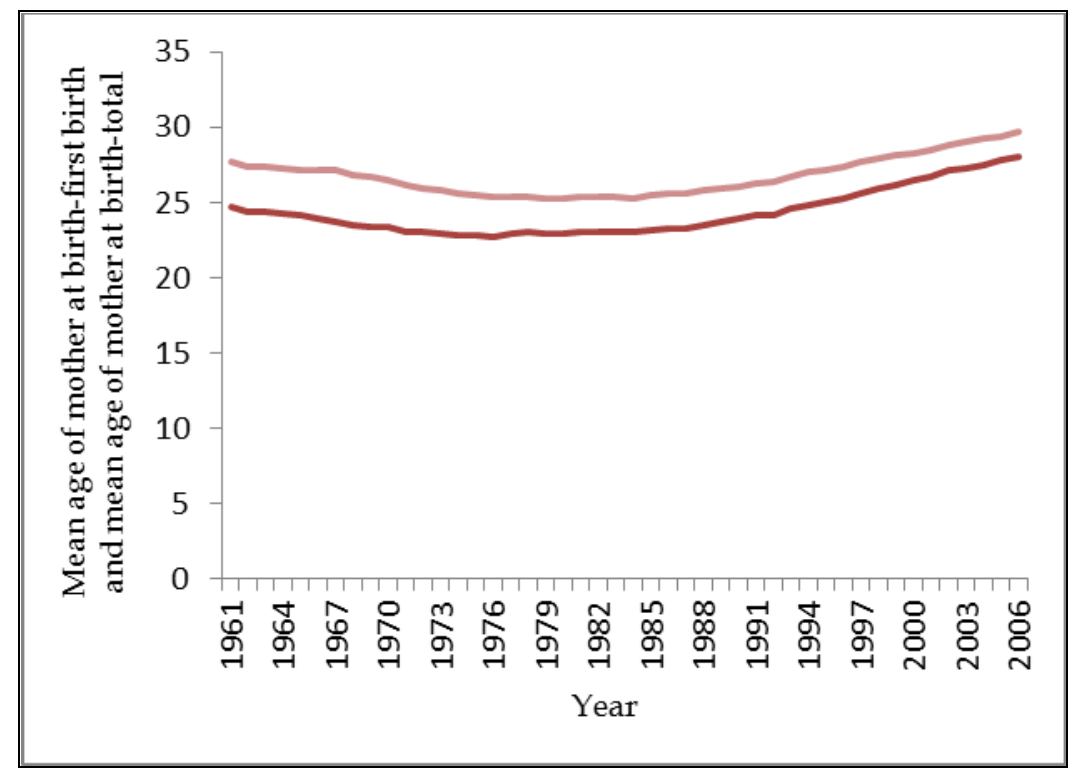

Fig. 5. Mean age mother at first birth (dark red line) and mean age of mother at birth-total (light red line) in the period from 1961 to 2006 in Slovenia

All these data to point to changes in the quantity and quality of the work performed at present by midwives employed in the thirteen maternity wards and maternity hospitals, and elsewhere in Slovenia (National Institute of Public Health of the Republic of Slovenia, 2011). The possible role of midwives in the early detection and prevention of BC in the future should thus be carefully appraised and evaluated.

\section{Midwives and breast cancer screening}

Study of midwifery has a long and distinguished tradition in Slovenia. The first School for midwives was established in 1753 in Ljubljana, the capital of Slovenia, following the decree 
issued by Maria Theresa, Empress of Austria, sovereign of all Slovenian lands at that time. Similar Schools for midwives were later also established in Graz, Celovec (Klagenfurt) and Trst (Trieste), all of them at least partly serving the Slovenian-speaking population. After 1924 Midwifery school in Ljubljana remained the only institution which educated midwives in Slovenia. At present the first-cycle degree Professional Higher Education Study Programme Midwifery at the Faculty of Health Sciences at the University of Ljubljana lasts three years (six semesters) and 30 students enrol in the programme each year. The majority of the enrolled students finish the study program and complete their study with a diploma work (Skoberne et al, 2011; Stanek Zidarič et al., 2009).

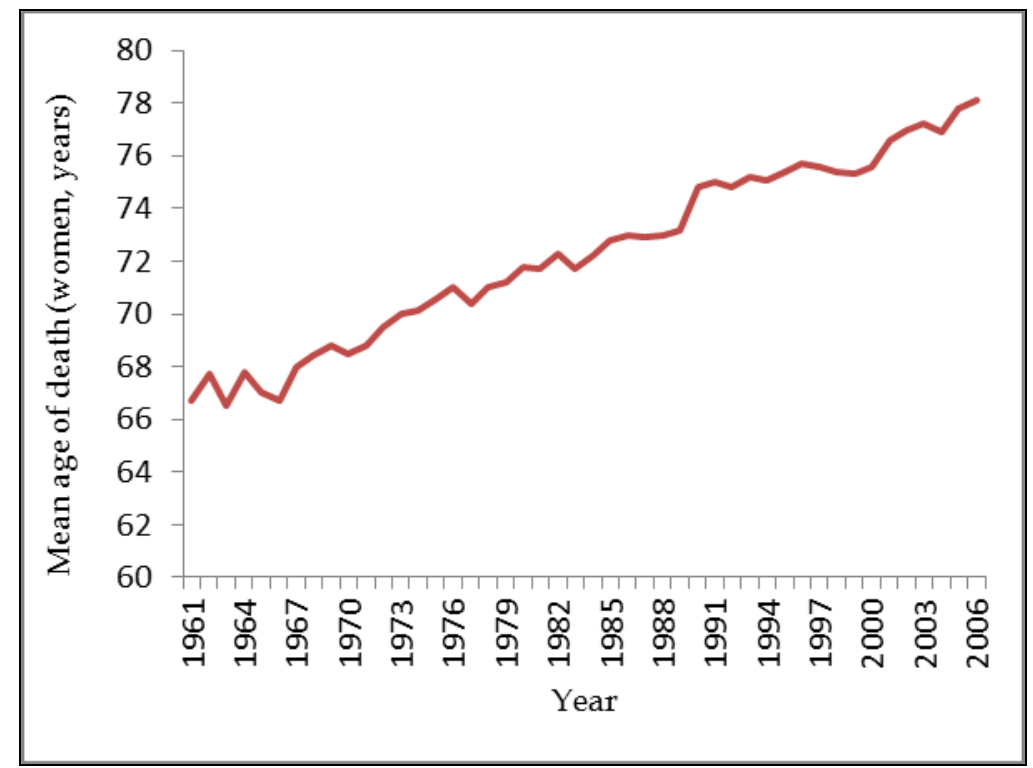

Fig. 6. Mean age of death in women (red line) in the period from 1961 to 2006 in Slovenia

Although it is not particularly emphasized in their curriculum (Stanek Zidarič et al., 2009; World Health Organization \& WHO Regional Office for Europe, 2001), midwifery students at the Faculty of Health Sciences in Ljubljana get a reasonable amount of insight into anatomy, histology and physiology of breasts, as well as into incidence, clinical and pathological characteristics, treatment and mortality of BC. They also learn some of the fundamentals about how to perform breast self-examination (BSE) and clinical breast examination (CBE) (Plesničar et al., 2004a; Plesničar et al., 2010; Stanek Zidarič et al., 2009). As a result, midwifery students have a favourable attitude toward BSE, they are of opinion that teaching BSE helps in detection of BC, and that teaching other women how to practice BSE ought to be one of their duties. They are also optimistic in their views of development and efficacy of BC detection and treatment in the future. This sort of attitude toward BC and BSE may have emerged from their specific education and from their inherent motivation to learn as much as possible about clinical, psychological and other problems that affect women with this disease (Plesničar et al., 2004a; Plesničar et al., 2010). All these qualities make them better informed about BC than other women (Budden, 1999; Fischer et al, 2003; 
Frank et al, 2000; Gigerenzer et al, 2009; Jirojwong \& MacLennan, 2002; Plesničar et al., 2004a; Plesničar et al., 2010). It should also be taken into account that due to their specific education and positive attitude toward BSE, midwifery students should be at the end of their study able to teach BSE to other women and perform CBE quite efficiently (Boulos et al, 2005; Miller et al., 2000; Mittra et al, 2010; Plesničar et al., 2004a; Plesničar et al., 2010).

In the majority of developed countries, including Slovenia, the emphasis is on the use of mammography screening tests focused on early BC detection. These tests enable the discovery of the disease in the early stages of its clinical development, thus improving the chances of longer survival of BC patients (Armstrong \& Nguyen, 1999; Dora-državni presejalni program za raka dojk, 2011; Frank et al, 2009; U.S. Preventive Services Task Force. 2009). In a number of studies, however, mammography screening has been shown to reduce breast cancer mortality significantly only for women aged 50-74 years. No benefit has been shown for CBE or BSE (Gøtzsche \& Nielsen, 2011; Jekel et al, 1996; Nelson et al, 2009). In addition, some of the studies have, among other problems, also pointed to disagreements about mammography screening tests' efficacy (Gøtzsche \& Nielsen, 2011). Harms of BC mammography screening were found to include false-positive results, biopsies and repeated imaging in women without cancer, risks of unnecessary treatment, increased radiation exposure and psychological damage (Gøtzsche \& Nielsen, 2011; Meissner et al, 2011; U.S. Preventive Services Task Force, 2009; Welch \& Black, 2010). Contrariwise, in Canadian National Breast Screening Study-2 trial mammography with CBE was compared to CBE alone in women aged 50-59 years and no difference in mortality from BC was observed between the two approaches at 13 years (Miller et al, 2000). These controversies have led to suggestions that decisions about participation in mammography screening tests for women should be made on an individualized basis (Berlin \& Hall, 2010; Hall, 2009; Meissner et al, 2011; Peres, 2010; Plesničar et al, 2010). The approach that requires work with women on an individual basis should certainly include greater sharing of information and decision making between patient or client and health expert, be that midwife, physician or nurse (Berlin \& Hall, 2010; Hall, 2009; Peres, 2010).

In Slovenia primary health care includes specialists in family medicine, paediatrics, psychiatry and gynaecology (Ministry of Health \& Government of Republic of Slovenia, 2011b; National Institute of Public Health of the Republic of Slovenia, 2011; Statistical Office of the Republic of Slovenia, 2011). In the year 2011 a number of family practices were upgraded to referral practices, in effect multidisciplinary teams, each one comprising a specialist in family medicine, a nurse and a certified nurse that perform certain activities in accordance with her/his jurisdiction and responsibilities. The aim of such referral practices is to increase quality, safety and cost effectiveness in patient treatment by transferring a number of tasks to the primary level. It is anticipated that each referral practice is involved in optimal integrated care adhering to chronic patient treatment protocols, prevention and optimal use of laboratory services of at least four of the following chronic conditions and treatments: heart failure, chronic obstructive pulmonary disease, asthma, depression, diabetes, benign hypertrophy of the prostate, thyroid diseases and anti-coagulation treatment (Ministry of Health \& Government of Republic of Slovenia, 2011b).

Following the aforementioned model of referral practices, it could probably be relatively easy to establish multidisciplinary teams that would among other activities also focus on early detection and prevention of BC. Each such team could comprise a specialist in gynaecology 
and obstetrics, a midwife and/or a nurse. In some circumstances, for example those distinctive of LMIC countries, midwives could perform their specific activities associated with BC alone. At least in the beginning, midwives could perform CBE as recommended in prevailing guidelines (Boulos et al, 2005; Meissner et al, 2011; Mittra et al, 2010; Plesničar et al, 2010; U.S. Preventive Services Task Force, 2009). Besides performing CBE with or without mammography, the activity of midwives could expand to informing women about breast health awareness (BHA). For women, accepting BHA would mean getting unbiased information about a wide range of breast problems such as breast pain and tenderness, breast asymmetry, nipple discharge, breasts considered to be too small or too large, or about breast lumps, bumps and thickenings (Mitchell, 2002). It would also mean being able to recognize normal appearance and structure of breasts during different periods of menstrual cycle and with regard to pregnancy and age, to recognize undue changes and inform midwife and physician in the multidisciplinary team about them immediately so they could refer these women to mammography tests when necessary (Mitchell, 2002; Plesničar et al., 2004b). Although BSE does not decrease BC mortality (Semiglazov et al, 2004; Thomas et al, 2002; U.S. Preventive Services Task Force, 2009), it can be regarded as an essential component of BHA that may contribute to early BC detection (Mitchell, 2002; Plesničar et al., 2010). Breast selfexamination is not much different from what the concept of BHA includes (Dowle et al, 1987; Philip et al, 1984; Plesničar et al., 2010) and in some opinions BHA should broaden the role of BSE (Austoker, 2003; Plesničar et al., 2010). The easiest way to increase BHA could thus be to teach BSE, and in this manner the role of midwives in early BC detection would be given even more prominence (Miller et al., 2000; Plesničar et al., 2004a, Plesničar et al., 2010).

Further on, midwives could take part in BC risk factor reduction or elimination and some other specific health promotion activities, all of them part of primary prevention, that would focus on introducing subtle and hardly measurable changes in women's and population's way of living with the aim of decreasing BC incidence in the longer term in Slovenia and elsewhere. These activities could include education about health behaviour modification with prolonged lactation, healthy lifestyle with regular physical activity, and proper nutrition to prevent obesity and harmful consumption of alcohol. For postmenopausal women these activities could also include the information about the risks of the use of hormonal replacement therapy (Armstrong \& Nguyen, 1999; Anderson et al 2008, DeSantis et al, 2011b; Henderson et al, 1996; Jekel et al, 1996; Kohler et al. 2011; Ravdin et al, 2007). All these activities and procedures would be carried out on an individual basis, in time gradually replacing mammography screening with individual BC case finding (Jekel et al, 1996).

Finally, it may be appropriate to cite comments of Otis Brawley, MD, chief medical officer of the American Cancer Society, with regard to prostate cancer screening and simply substitute the word breast for prostate (Berlin \& Hall, 2010) and make a mention of midwives in the context: adequately trained and experienced midwives could help every woman take an informed decision about what is right for her personally after hearing a balanced presentation of potential benefits and risks of screening. All in the medical and advocacy communities should respect that choice (Brawley, 2009, as cited in Berlin \& Hall, 2010)

\section{Discussion}

The changes in demographics and in the incidence rate of BC in the last decades surely represent serious and important challenges for health care system in Slovenia. Despite the content and context of these changes in Slovenia, the number of midwifery graduates, the 
contents of midwifery students' curriculum, the numbers of maternity wards and maternity hospitals have remained more or less constant and without sensible changes in recent years.

All the data about changes in demographic indicators with potential impact on the increase of BC incidence rates in Slovenia may not have been shown in this report. However, the changes in number of live births, number of live births per 1,000 population, total fertility rate, age of mother at first birth and age of mother at birth in total, and mean age of death in women in the period from 1961 to 2006, certainly suggest that there are now many more women exposed to the risk of BC than four or five decades ago (Armstrong \& Nguyen, 1999; Bryant, 2004; Curado et al (Eds.), 2009; Henderson et al, 1996; International Agency for Research in Cancer, 2008; Soerjomataram et al 2008). The changes in demographic indicators and the increase in the incidence rate of $\mathrm{BC}$ in Slovenia in the last decades should at the very least stimulate a debate about changes in priorities in activities of midwives and related experts and specialists today and in the future. One of the future priorities for midwives could be early detection and prevention of $\mathrm{BC}$ that would include informing women about BHA and about risk factors of BC on an individual basis. In Slovenia and some other countries midwives already occupy a central position in education of young women about sexual and reproductive health, family planning and contraception (Ministry of Health \& Government of Republic of Slovenia, 2011a). It should not be difficult to imagine the midwives establishing a trustful and confidential professional relationship with women in late teens or early twenties, informing them about $\mathrm{BHA}, \mathrm{BSE}, \mathrm{CBE}, \mathrm{BC}$, age adjusted $\mathrm{BC}$ risk factors and their reduction or elimination, performing $\mathrm{CBE}$ according to guidelines and later in their lives informing them about BC mammography screening programs.

About two thirds of all cancer cases are diagnosed in economically developed countries and about one third in LMIC countries (Forouzanfar et al, 2011; International Agency for Research in Cancer, 2008; Mellstedt, 2006). In the year 2010 the majority of women with BC in economically and industrially developed countries were aged 50 years or more. However, in developing countries there were twice as many women with BC aged 15-49 years than in developed countries, with the incidence rate of $\mathrm{BC}$ overall rising rapidly (Forouzanfar et al, 2011; International Agency for Research in Cancer, 2008; Mittra, 2011; Yeole \& Kurkure, 2003). In view of these developments, it is agreed that mammography is not an appropriate $\mathrm{BC}$ screening test for LMIC countries. It is expensive, technologically complex and requires highly skilled experts and quality control (Berlin \& Hall, 2010; Frank et al, 2000; Harford, 2011; Mittra, 2011; Nelson et al, 2009; U.S. Preventive Services Task Force, 2009). Conversely, CBE is relatively easy and inexpensive to perform (Mittra, 2011; Nelson et al, 2009). However, its effectiveness in reducing BC mortality is still regarded as controversial (Nelson et al, 2009), although the results of Canadian National Breast Screening Study-2 strongly suggest such an effect (Miller et al, 2000; Mittra, 2011). Two major randomized trials in Mumbai and Cairo comparing CBE and no screening are now addressing this dilemma. In Mumbai CBE and education are performed by female health workers who underwent five months of additional training, while in Cairo examinations are performed by female physicians who received two months of special training (Boulos et al, 2005; Mittra et al, 2010). In both studies there have been difficulties in assuring follow-up, a problem in many cases due to low levels of health awareness and motivation in screened communities (Miller, 2008; Mittra et al, 2010; Mittra, 2011). It is intriguing to speculate that this problem may otherwise not be encountered in Slovenia or other developed countries. These two studies may confirm the effectiveness of CBE and its use in LMIC countries may obviate the 
perceived need for establishing complex mammography screening programs, especially since a large proportion of women diagnosed with BC in these countries are aged 15-49 years.

The results of Mumbai and Cairo studies may strengthen the arguments for use of CBE by midwives in Slovenia and elsewhere. Altogether, the activities of midwives working with women on an individual basis, whether alone or as a part of a multidisciplinary team in a referral practice, including informing and teaching women about $\mathrm{BHA}$, giving other information and performing CBE, could be described as lifetime breast health monitoring, a development of practice described already more than thirty years ago (Breslow \& Somers, 1977).

\section{Conclusion}

It is imperative to understand the need to change and supplement secondary prevention of $\mathrm{BC}$ from mammography screening to individual $\mathrm{BC}$ case finding that would include mammography when necessary. In the future, individual BC case finding should be further developed to lifetime breast health monitoring, making midwives role in multidisciplinary teams indispensable. In certain surroundings and circumstances, especially in LMIC countries, midwives could also operate alone. In Slovenia and other parts of the world, including LMIC countries, where increasing incidence rate of $\mathrm{BC}$ and demographic changes represent a serious public health issue, their skills, proficiency, positive attitudes and goodwill should not be left unused.

\section{References}

Armstrong, B.K. \& Nguyen, H.L. (1999). Breast cancer, In: Cancer Facts. A Concise Oncology Text, Bishop, J.F., Editor, pp. 127-132, Interwood Academic Publishers, ISBN 905702-470-5, Amsterdam, The Netherlands

Anderson, B.O.; Yip, C.H.; Smith, R.A.; Shyyan, R.; Sener, S.F.; Eniu, A.; Carlson, R.W.; Azavedo, R. \& Harford, J. Guideline implementation for breast healthcare in lowincome and middle-income countries. Overview of the Breast Health Initiative Global Summit 2007. Cancer, Vol. 113, No. 8, (June 2008), pp. 2221-2243, ISSN 10970142

Austoker, J. (2003). Breast self examination. British Medical Journal, Vol. 326, No. 7379, (January 2003), pp. 1-2, ISSN 1468-5833

Berlin, L. \& Hall, F.M. (2010). More mammography muddle: emotions, politics, science, costs, and polarization. Radiology, Vol. 255, No. 2, (May 2010), pp. 311-316, ISSN 1527-1315

Boulos, S.; Gadallah, M.; Neguib, S.; Essam, E.; Youssef, A.; Costa, A.; Mittra, I. \& Miller, A.B. (2005). Breast screening in the emerging world: high prevalence of breast cancer in Cairo. Breast (Edinburgh, Scotland), Vol. 14, No. 5, (October 2005), pp. 340 346, ISSN 0960-9776

Bryant, H. (2004). Breast cancer in Canadian women. BMC Women's Health, Vol. 4, Suppl. 1, (August 2004), pp. S12, ISSN 1472-6874 
Budden, L. (1999). Student nurses' breast self-examination health beliefs, attitudes, knowledge, and performance during the first year of a preregistration degree program. Cancer Nursing, Vol. 22, No. 6, (December 1999), pp. 430-437, ISSN 15389804

Cancer Registry of Republic of Slovenia. (2010). Cancer Incidence in Slovenia; 2007. Report No. 49, Institute of Oncology, ISSN 1318-2471, Ljubljana, Slovenia

Centers for Disease Control and Prevention. (2007). Decline in breast cancer incidenceUnited States, 1999-2003. MMWR. Morbidity and Mortality Weekly Report, Vol. 56, No. 22, (June 2007). pp. 549-553, ISSN 0149-2195

Curado, M.P.; Edwards, B.; Shin, H.R.; Storm, H.; Ferlay, J.; Heanue, M. \& Boyle, P. (Eds.). Cancer Incidence in Five Continents. Volume IX. IARC Scientific Publications No. 160. International Agency for Research on Cancer, ISBN 978-92-832-2160, Lyon, France

DeSantis, C.; Howlader, N.; Cronin, K.A. \& Jemal, A. (2011) Breast cancer incidence rates in US women are no longer declining. Cancer epidemiology, Biomarkers $\mathcal{E}$ Prevention : A Publication of the American Association for Cancer Research, Cosponsored by the American Society of Preventive Oncology, Vol. 20, No. 5, (May 2011), pp. 733-739, ISSN 1055-9965

DeSantis, C.; Siegel, R.; Bandi, P. \& Jemal, A. (2011). Breast cancer statistics, 2011. CA: A Cancer Journal for Clinicians, Vol. 61, No. 6, (November/December, 2011), pp. 408418, ISSN 1542-4863

Dora-državni presejalni program za raka dojk. (2011). Presejanje za raka dojk. In: Doradržavni presejalni program za raka dojk, Date of access: October 25th, 2011, Available from: <http://dora.onko-i.si/presejanje_za_raka_dojk/index.html>

Dowle, C.S.; Mitchell, A.; Elston, C.W.; Roebuck, E.J.; Hinton, C.P.; Holliday, H. \& Blamey, R.W. (1987). Preliminary results of the Nottingham breast self-examination education programme. The British Journal of Surgery, Vol. 74, No. 3, (March 1987), pp. 217-219, ISSN 1365-2168

Fischer, V.; Pabst, R. \& Nave, H. (2003). Seminar in breast self-examination for female medical students integrated into a human gross anatomy course. Clinical Anatomy (New York, N.Y.), Vol. 16, No. 2, (March 2003), pp.160-164, ISSN 08973806

Forouzanfar, M.H.; Foreman, K.J.; Delossantos, A.M.; Lozano, R.; Lopez, A.D.; Murray, C.J.L. \& Naghavi, M. (2011). Breast and cervical cancer in 187 countries between 1980 and 2010: a systematic analysis. The Lancet, Vol. 378, No. 9801, (October 2011), pp. 1461-1484, ISSN 0099-5355

Frank, E.; Rimer, B.K.; Brogan, D. \& Elon, L. (2000). U.S. women physicians' personal and clinical breast cancer screening practices. Journal of Women's Health $\mathcal{E}$ Gender Based Medicine, Vol. 9, No. 7, (September 2000), pp. 791-801, ISSN 1524-6094

Gigerenzer, G.; Mata, J. \& Frank, R. (2009). Public knowledge of benefits of breast and prostate cancer screening in Europe. Journal of National Cancer Institute, Vol. 101, No. 8, (April 2009), pp. 1216-1220, ISSN 1460-2105

Gøtzsche, P.C. \& Nielsen, M. (2011). Screening for breast cancer with mammography (review). Cochrane Database of Systematic Reviews, No. 1, (January 2011), pp. 1-47, ISSN 1469-493X 
Hall, F.M. (2009). The radiology report of the future. Radiology, Vol. 251, No. 2, (May 2009), pp. 313-316, ISSN 1527-1315

Harford, J.B. (2011). Breast cancer early detection in low-income and middle-income countries: do what you can versus one size fits all. The Lancet Oncology, Vol. 12, No. 3, (March 2011), pp. 306-312, ISSN 1470-2045

Henderson, B.E.; Pike, M.C.; Bernstein, L. \& Ross, R.K. (1996). Breast Cancer, In: Cancer Epidemiology and Prevention, Schottenfeld, D. \& Fraumeni, J.F., Editors, pp. 10221039, Oxford University Press, New York, New York, USA

Ilić, M.; Kalin, K.; Povhe, J.; Šter, D. \& Žnidaršič, T. (2008). Population of Slovenia 2006. Results of Surveys No. 831/2008. Statistical Office of the Republic of Slovenia, ISBN 978-961239-170-9, Ljubljana, Slovenia

International Agency for Research in Cancer. (2008). Breast Cancer Incidence and Mortality Worldwide in 2008. Summary, In: Globocan 2008. Cancer Incidence and Mortality Worldwide in 2008, Date of access November 8th, 2011, Available from: <http://globocan.iarc.fr/factsheets/cancers/breast.asp>

Jekel, J.F.; Elmore, J.G. \& Katz, D.L. (1996). Epidemiology, Statistics and Preventive Medicine, 1st edition. WB Saunders Company, ISBN 0-7216-5258-1, Philadelphia, Pennsylvania, USA

Jirojwong, S. \& MacLennan R. (2003). Health beliefs, perceived self-efficacy, and breast selfexamination among Thai migrants in Brisbane. Journal of Advanced Nursing, Vol. 41, No. 3, (February 2003), pp. 241-249, ISSN 1365-2648

Kerlikowske, K.; Miglioretti, D.L.; Buist, D.S.; Walker, R.; Carney, P.A. \& National Cancer Institute-Sponsored Breast Cancer Surveillance Consortium. (2007). Declines in invasive breast cancer and use of postmenopausal hormone therapy in a screening mammography population. Journal of National Cancer Institute, Vol. 99, No. 7, (September 2007), pp.1335-1339, ISSN 1460-2105

Kohler, B.A.; Ward, E.; McCarthy, B.J.; Schymura, M.J.; Ries, L.A.G.; Eheman, C.; Jemal, A.; Anderson, R.M.; Ajani, U.A. \& Edwards, B.K. (2011). Annual report to the nation on the status of cancer, 1975-2007, featuring tumors of the brain and other nervous system. Journal of National Cancer Institute, Vol. 103, No. 9, (May 2011), pp. 1-23, ISSN 1460-2105

Meissner, H.I.; Klabunde, C.N.; Han, P.K.; Benard, V.B. \& Breen, N. (2011). Breast cancer screening beliefs, recommendations, and practices. Primary Care physicians in the United States. Cancer, Vol. 117, No. 14. (July 2011), pp. 3101-3111, ISSN 10970142

Mellstedt, H. (2006). Cancer initiatives in developing countries. Annals of Oncology, Vol. 17, Suppl. 8, (June 2006). pp. viii24-viii31, ISSN 1569-8041

Miller, A.B.; To, T.; Baines, C.J. \& Wall, C. (2000). Canadian National Breast Screening Study2: 13-year results of a randomized trial in women aged 50-59 years. Journal of National Cancer Institute, Vol. 92, No. 18, (September 2000), pp. 1490-1499, ISSN 1460-2105

Miller, A.B. (2008). Practical applications for clinical breast examination (CBE) and breast self-examination (BSE) in screening and early detection of breast cancer. Breast Care (Basel, Switzerland), Vol. 3, No. 1, (February 2008), pp. 17-20, ISSN 16613791 
Ministry of Health \& Government of Republic of Slovenia. (2011a). Date of Access: October 26 th 2011, Available from: <http:/ / www.mz.gov.si/si>

Ministry of Health \& Government of Republic of Slovenia. (2011b). Referenčna ambulanta. In: publikacije in druga gradiva, Date of Access: October 23rd, 2011, Available from: <http://www.mz.gov.si/si/mz_za_vas/zdravstveno_varstvo/referencne_ambula nte/

Mitchell, A. (2002). Breast health awareness, In: Evidence-based health promotion. $4^{\text {th }}$ edition, E.R. Perkins, I. Simnet, L. Wright, Editors, pp. 266-274, John Wiley \& Sons, ISBN 0471-97851-5, Chichester, England

Mittra, I.; Mishra, G.A.; Singh, S.; Aranke, S.; Notani, P.; Badwe, R.; Miller, A.B.; Daniel, E.E.; Gupta, S.; Uplap, P.; Thakur, M.H.; Ramani, S.; Kerkar, R.; Ganesh, B. \& Shastri, S.S. (2010). A cluster randomized, controlled trial of breast and cervix cancer screening in Mumbai, India: methodology and interim results after three rounds of screening. International Journal of Cancer. Journal International du Cancer, Vol. 126, No. 4, (February 2010), pp. 976-984, 0020-7136

Mittra, I. (2011). Breast cancer screening in developing countries. Preventive Medicine, Vol. 53, No. 3, (June 2011), pp. 121-122, ISSN 1096-0260

National Institute of Public Health of the Republic of Slovenia. (2011). In: Podatkovne zbirkezdravstveni statistični podatki, Date of access October 21st, 2011, Available from: <http://www.ivz.si/

Mp.aspx?ni=46\&pi=5\&_5_id=1771\&_5_PageIndex=0\&_5_groupId=185\&_5_newsC ategory=\&_5_action=ShowNewsFull\&pl=46-5.0.>

Nelson, H.D.; Tyne, K.; Naik, A.; Bougatsos, C.; Chan, B.; Nygren, P. \& Humphrey, L. (2009). Screening for breast cancer: systematic evidence review update for the US preventive services task force. Evidence Review Update, No. 74. AHRQ Publication No. 10-05142EF-1. Rockville, Maryland, USA

Peres, J. (2010). Mammography screening: after the storm, calls for more personalized approaches. Journal of National Cancer Institute, Vol. 102, No. 1, (January 2010), ISSN 1460-2105

Philip, J.; Harris, W.G.; Flaherty, C.; Joslin, C.A.; Rustage, J.H. \& Wijesinghe, D.P. (1984). Breast self-examination: clinical results from a population-based prospective study. British Journal of Cancer, Vol. 50, No. 1, (July 1984), pp. 7-12, ISSN 0007-0920

Plesničar, A.; Goličnik, M. \& Kralj, B. (2004a). Midwifery students and breast selfexamination. The Breast Journal, Vol. 10, No. 6, (November/December 2004), pp. 560, ISSN 1075-122X

Plesničar, A.; Kovač, V. \& Kralj, B. (2004b). Breast cancer and breast health awareness as an evolving health promotion concept. Radiology and Oncology, Vol. 38, No. 1, (March 2004), pp. 27-34, ISSN 1318-2099

Plesničar, A.; Goličnik, M.; Kirar Fazarinc, I.; Kralj, B.; Kovač, V. \& Kores Plesničar, B. (2010). Attitudes of midwifery students towards teaching breast self-examination. Radiology and Oncology, Vol. 44, No. 1, (March 2010), pp. 52-56, ISSN 13182099

Ravdin, P.M.; Kronin, K.A.; Howlader, N.; Berg, C.D.; Chlebowski, R.T.; Feuer, E.J.; Edwards, B.K. \& Berry, D.A. (2007). The decrease in breast-cancer incidence in 2003 
in the United States. New England Journal of Medicine, Vol. 356, No. 16, (April 2007), pp. 1670-1674, ISSN 0028-4793

Semiglazov, V.F.; Manikhas, A.G.; Moiseenko, V.M.; Protsenko, S.A.; Kharikova, R.S.; Seleznev, I.K.; Popova, R.T.; Migmanova, N.Sh.; Orlov, A.A.; Barash, N.Iu.; Ivanova, O.A. \& Ivanov V.G. (2003). Results of a prospective randomized investigation [Russia (St. Petersburg)/WHO] to evaluate the significance of selfevaluation for the early detection of breast cancer. Voprosy Onkologii, Vol. 49, No. 4; (April 2003), pp. 434-441, ISSN 0507-3758

Slora-Slovenia and Cancer. (2011). Slovenian data. In: Website on cancer information in Slovenia and other countries, Date of access: October 12th, 2011, Available from: $<$ http://www.slora.si/en/analizaslo>

Skoberne, M.; Mivšek A.P.; Zakšek, T. \& Skubic, M. (2011). Midwifery. In: Faculty of health sciences. $1^{\text {st }}$ edition, D. Rugelj, Editor, pp. 31-37, Faculty of Health Sciences, ISBN 978-961-6808-22-4, Ljubljana, Slovenia

Soerjomataram, I.; Pukkala, E.; Brenner, H. \& Coebergh, J.W. (2008). On the avoidability of breast cancer in industrialized societies: Older mean age at first birth as an indicator of excess breast cancer risk. Breast Cancer Research and Treatment, Vol. 111, No. 2, (September 2008), pp. 297-302, ISSN 0167-6806

Stanek Zidarič, T.; Mivšek, A.P.; Skoberne, M.; Skubic, M. \& Zakšek, T. (2009). Professional higher education study programme 1st cycle degree - midwifery, University of Ljubljana, Faculty of Health Sciences, ISBN 978-961-6063-99-9, Ljubljana, Slovenia

Statistical Office of the Republic of Slovenia. (2011). In: Demography and social statistics, Date of access: October 19th 2011 , Available from: <http://www.stat.si/eng/tema_demografsko.asp?SklopID=3>

Thomas, D.B.; Gao, D.L.; Ray, R.M.; Wang, W.W.; Allison, C.J.; Chen, F.L.; Porter, P.; Hu, Y.W.; Zhao, G.L.; Pan, L.D.; Li, W.; Wu, C.; Coriaty, Z.; Evans, I.; Lin, M.G.; Stalsberg, H. \& Self, S.G. (2002).Randomized trial of breast self-examination in Shanghai: final results. Journal of National Cancer Institute; Vol. 94, No. 19, (October 2002), pp. 1445-1457, ISSN 1460-2105

U.S. Preventive Services Task Force. (2009). Screening for breast cancer: U.S. preventive services task force recommendation statement. Annals of Internal Medicine, Vol. 151; No. 10, (November 2009), pp. 716-726, ISSN 1539-3704

Welch, H.G. \& Black, W.C. (2010). Overdiagnosis in cancer. Journal of National Cancer Institute, Vol. 102, No. 9, (April 2010), pp. 605-613, ISSN 1460-2105

World Health Organization; WHO Regional Office for Europe. (2001). Nurses and Midwives for Health. WHO European Strategy for Nursing and Midwifery Education (1 ${ }^{\text {st }}$ edition), WHO Regional Office for Europe, ISBN 92-890-1191-2, Copenhagen, Denmark

Yip, C.H.; Cazap, E.; Anderson, B.O.; Bright, K.L.; Caleffi, M.; Cardoso, F.; Elzawawy, A.M.; Harford, J.B.; Krygier, G.D.; Masood, S.; Murillo, R.; Muse, I.M.; Otero, I.V.; Passman, L.J.; Santini, L.A.; Corrêa Ferreira da Silva, R.; Thomas, D.B.; Torres, S.; Zheng, Y. \& Khaled, H.M. (2011). Breast cancer management in middle-resource countries (MRCs): Consensus statement from the Breast Health Global Initiative. Breast (Edinburgh, Scotland), Vol. 20, Suppl. 2, (April 2011), pp. S12-S19, ISSN 09609776 
Yeole, B.B. \& Kurkure A. P. (2003). An epidemiological assessment of inceasing incidence and trends in breast cancer in Mumbai and other sites in India, during the last two decades. Asian Pacific Journal of Cancer Prevention, Vol. 4, No. 1, (January-March 2003), pp. 51-56, ISSN 1513-7363 


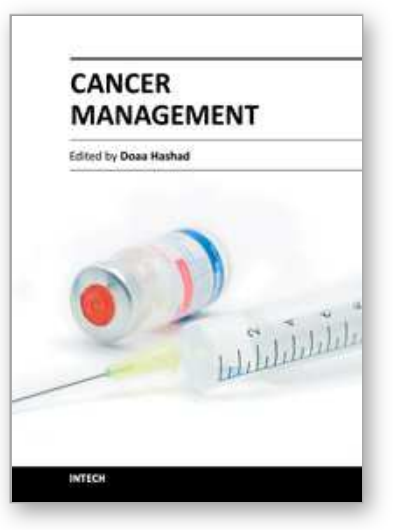

\author{
Cancer Management \\ Edited by Dr. Doaa Hashad
}

ISBN 978-953-51-0650-0

Hard cover, 94 pages

Publisher InTech

Published online 13, June, 2012

Published in print edition June, 2012

Cancer remains a major clinical challenge as a cause of death due to its frequent poor prognosis and limited treatment options in many cases. Cancer management book addresses various cancer management related topics including new approaches for early cancer detection and novel anti-cancer therapeutic strategies. This book is a collection of studies and reviews written by experts from different parts of the world to present the most up-to-date knowledge on cancer management.

\title{
How to reference
}

In order to correctly reference this scholarly work, feel free to copy and paste the following:

Andrej Plesničar, Klaudia Urbančič, Suzana Mlinar, Božo Kralj, Viljem Kovač and Blanka Kores Plesničar (2012). Early Detection and Prevention of Breast Cancer: The Increasing Importance of Midwives in the Future, Cancer Management, Dr. Doaa Hashad (Ed.), ISBN: 978-953-51-0650-0, InTech, Available from: http://www.intechopen.com/books/cancer-management/early-detection-and-prevention-of-breast-cancer-theincreasing-importance-of-midwives-in-the-fut

\section{INTECH}

open science / open minds

\section{InTech Europe}

University Campus STeP Ri

Slavka Krautzeka 83/A

51000 Rijeka, Croatia

Phone: +385 (51) 770447

Fax: +385 (51) 686166

www.intechopen.com

\section{InTech China}

Unit 405, Office Block, Hotel Equatorial Shanghai

No.65, Yan An Road (West), Shanghai, 200040, China

中国上海市延安西路65号上海国际贵都大饭店办公楼405单元

Phone: +86-21-62489820

Fax: +86-21-62489821 
(C) 2012 The Author(s). Licensee IntechOpen. This is an open access article distributed under the terms of the Creative Commons Attribution 3.0 License, which permits unrestricted use, distribution, and reproduction in any medium, provided the original work is properly cited. 